\title{
Educational processes in distance learning for the training of health professionals: an integrative literature review
}

\begin{abstract}
Objective: Identify innovations in educational processes in distance learning for the training of health professionals.
\end{abstract}

Method: Integrative review of the literature in the Pubmed, Bireme, Scopus and Lilacs databases from 2005 to 2017 , with the selection of 27 articles.

Results: It was found for how to evaluate the educational process for the tested technology of $44.4 \%$ (12), Technology Developed 18.5\% (05) and the two approaches concomitantly in the survey $37.1 \%$ (10). The educational processes used technologies such as the Virtual Learning Environment, WebQuest, Teleconference, radio, virtual playbook, multimedia, and hypermedia, as well as individualized systems to meet the need for improvement in the teaching-learning process.

Conclusion: The resources used show a growing need for the use of images as an audiovisual form explored in most of the educational processes described and innovations such as the use of radio and animations.
Volume 8 Issue I - 2019

\author{
Jacqueline de Almeida Gonçalves Sachett, \\ Isabela Cristina de Miranda Gonçalves, \\ Leonardo Naves dos Reis, Waldeyde \\ Oderilda Magalhães dos Santos, Desirée \\ Emelly Dantas Gomes, Sibila Lilian Osis \\ University of the State of Amazonas, Brazil
}

Correspondence jacqueline de Almeida Gonçalves Research and Development Center UNA-SUS Amazônia, University of the State of Amazonas, Av. Carvalho Leal, I.777 . Cachoeirinha, Manaus - AM, CEP: 69065-00I Brazil, Tel +55 92 3878 435I, Email jac.sachett@gmail.com

Received: January 29, 2019 | Published: February 13, 2019

Keywords: distance learning, health professional, educational technology

\section{Introduction}

Education is in a constant process of change, which attempts to keep pace with the new millennium. Challenges, difficulties, and problems that if routed creatively and innovatively, will become opportunities. Rethinking educational practices, self-development, changing roles, and effective use of new technologies in educational processes all contribute to restructuring the teaching-learning process. With globalization shortening the distances, where everything is connected and Information and Communication Technologies (ICT) increasingly present in people's daily lives, this fact propels a favorable and open scenario for the discussions in favor of democratization of education. In this context, distance education allows the approximation of technology to educational processes, constructions of training spaces for learning and relearning of concepts formed in and outside the workplace. In Brazil, Decree No. 2,494, dated February 10, 1998, of the Presidency of the Republic, regulates article 80 of the Law on Guidelines and Bases of National Education (LDB) on distance modality. ${ }^{1}$ The Ministry of Education (MEC) defines Open and Distance Learning (ODL) as "the educational modality in which students and teachers are separated, physically or temporally and, therefore, it is necessary to use means and technologies of information and communication. This modality is regulated by specific legislation and can be implemented in basic education (youth and adult education, technical secondary vocational education) and undergraduate education". ${ }^{2}$ When it comes to numbers, the Brazilian Association of Distance Education (ABED) annually conducts the census regarding distance learning in Brazil. The last sense made available in September 2017 shows the increase in the positive complexity, expansion and maturation of the supply and operation of learning through technological mediation in the country, characteristics of which every educational community can pride. ${ }^{3}$
Distance Learning allowed access to continuing education at all professional levels, complementing in an important way the formal academic formation. MEC invests in actions that facilitate access to superior education positions through programs such as the University for All (ProUni), the Open University of Brazil (UAB) and the Student Funding Fund for Superior Education (Fies) or in the expansion of the public school system, through the Program to Support Restructuring and Expansion Plans of Federal Universities (Reuni). The Open University of the Unified Health System (UNA-SUS) was created to meet the training and continuing education needs of the Unified Health System (SUS) professionals, through the development of the ODL modality in the health area. ${ }^{4}$ The Open University System of SUS - UNA-SUS was created by the Ministry of Health in 2010 to attend the training and continuing education needs of health professionals working in the SUS. The System is composed of three elements: The Collaborative Network of Superior Education Institutions - which currently has 35 institutions, the Collection of Educational Resources in Health (ARES) and the Arouca Platform. One of the objectives of UNA-SUS is the permanent education, aiming at solving problems present in the day-to-day of health professionals working in the SUS. For this, the courses offered by the Network have a practical and dynamic approach, in several levels of academic training, easily accessed and entirely free. All the courses are in the ODL modality to facilitate the access of the health professionals to the courses. ${ }^{1}$ It is known that the current scenario of health in Brazil is not favorable, being able to cite as examples the long queues both to try to make an appointment and to be assisted, and among other problems conveyed by the media. Thus, the quality of health care in Brazil may be related to the training and qualification of health professionals working in the SUS. ${ }^{5}$

In this context, ODL becomes a strengthening tool for the SUS in what concerns permanent education and as a strategy of innovation 
in the training and qualification of health professionals, for example, the data of the Arouca Platform that in December of 2017 registered $1,162,069$ (one million, one hundred sixty-two thousand, sixty-nine) health professionals enrolled in the various courses offered by UNASUS. That is, professionals are seeking continuous knowledge in health, which in addition to contributing to professional qualification, also contributes to the consolidation of a model of health promotion and attention in the most equitable and democratic country. Distance learning presents challenges that go beyond those existing in classroom courses, in a way, ODL is an innovative process. The separation between the actors, the profile of the students, the need for student autonomy, pedagogical action and interaction methodologies are examples of differential elements that imply specific teaching conditions of the modality. The use of virtual scenarios, for example, is an alternative that allows the adequate use of multimedia tools to present situations-problems, which accompanies other learning objects, such as videos, games and evaluative activities. Another model of teaching is currently used are AVAs, which facilitates the dissemination of knowledge and, especially, access to courses without the need to move the student to a specific place of study. Another concept, much related to the use of virtual scenarios, is gamification, which combines some elements of games to achieve specific purposes, such as launching challenges, using strategies, winning space, rewards, among others. In this way, gamification helps to enrich the virtual scenarios, enabling the conception of playful elements in order to keep the student more engaged in their activities, at the same time that the objectives of the educational resources used must be achieved. With this, the uses of innovative methodologies are significant, since it allows the interactivity and the best stimulus to learning. ${ }^{6}$ Intervening in this scope of training needs of health professionals, using technological innovations for the best teachinglearning, and this article aims to identify innovations in educational processes in ODL for the training of health professionals.

\section{Methods}

This was an integrative review of the literature, focusing on the educational processes of distance education applied to health professionals through analysis, organization, and interpretation of the research objective. ${ }^{7}$ The present integrative review was based on six steps: 1) identification of the problem; 2) literature search and article search; 3) evaluation of the articles in pairs; 4) analyze of articles included for review; 5) evaluation and interpretation of results; and 6) presentation and discussion of the review. ${ }^{7}$ In addition, the PICO strategy was adopted for the construction of the object of study (Table 1). Thus the guiding question was elaborated as: What is (are) the distance education strategy (s), produced or implemented through virtual learning environments, more efficient for health professionals?

The review was performed based on the Prisma instrument Preferred Reporting Items for Systematic Reviews and Meta-Analyzes (Figure 1). The databases used for the paired search were Pubmed (U.S. National Library of Medicine), BVS (Virtual Health Library), Scopus and Lilacs. The following descriptors were used: Distance Learning, Educational Technologies, Information Technology, Strategies, Educational Evaluation, Educational Process and Health Personnel, according to DeCS terminology, Virtual Health Library (BVS). The inclusion criteria were: studies on educational processes in distance learning applied to health professionals; free access articles; available online in full; in Portuguese or English and published in the period 2005 to 2017. Literature review articles were excluded and those that did not contain an educational process produced or implemented.

In this step, two independent researchers evaluated the articles that were selected from the criteria defined to reach consensus. The divergent studies were discussed on the basis of established criteria in order to avoid selection biases. The agreement between the assessors in this study was confirmed by the Kappa coefficient of 0.88 . The selection of articles was carried out between August and December 2017 by two researchers in different ways. After the selection of the articles, they were evaluated in the content of the title and in the summary also in pairs and later a comparison were made between the researchers on the content and attendance to the proposed theme.

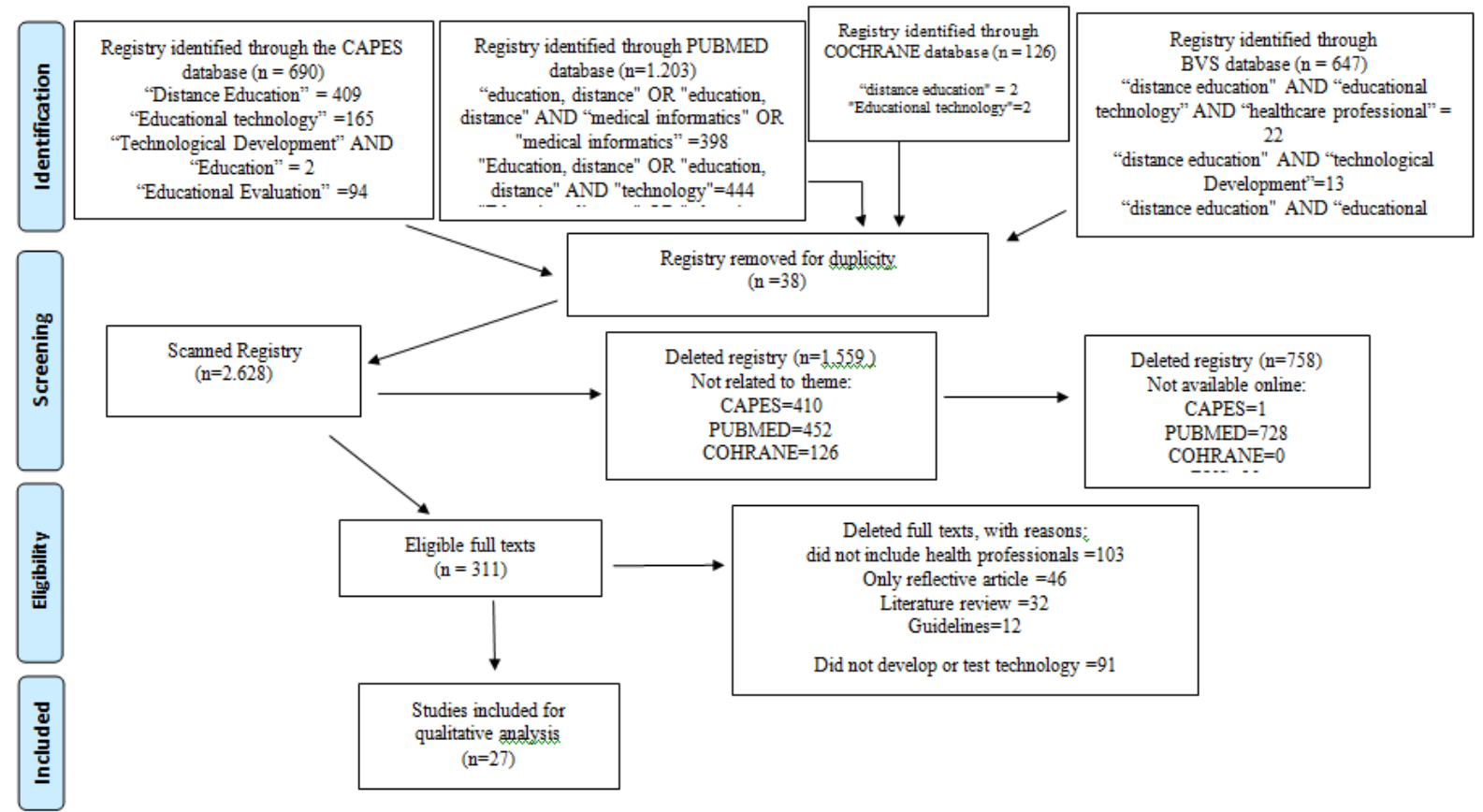

Figure I Flowchart for selection of articles included in the review - Manaus, Brazil, 2018. 
Table I Description of the PICO strategy for the search of educational processes for health professionals - Manaus AM, Brazil, 20 I8

Source: authors, 2018

Population:

Health professionals

P Superior level professionals (nurses, doctors, dentists, pharmacists, physiotherapists, etc.).

Technical level professionals (nursing technicians, pharmacy technicians, radiology technicians, etc.).

Primary level professionals (community health agents).

I Efficient strategies for distance learning, produced or implemented through virtual learning environments (moodle, google and others)

Comparison between different pedagogical models of ODL.

C Comparison between different types of learning objects.

Comparison between the different types of virtual learning environments used in ODL.

Analysis of the advantages and disadvantages of the different pedagogical models of ODL, so that it is possible to scale them according to higher or lower quality in relation to different aspects.

Advantages and disadvantages of different types of learning objects, so that it is possible to scale them according to higher or lower quality in relation to different aspects.

Advantages and disadvantages of the different types of virtual learning environments used in ODL, so that it is possible to scale them according to higher or lower quality in relation to different aspects.

\section{Results}

The selection consisted of a total of 27 articles that addressed technologies developed and tested individually or simultaneously. The studies on educational processes for the training of health professionals were similarly characterized in relation to the origin of the publications for national and international. Regarding the researchers, it was observed that the predominance link was for universities (Table 2). Based on Table 2, we found for the evaluation method of the educational process for the tested technology of $44.4 \%$ (12), Technology Developed $18.5 \%(05)$ and the two approaches concomitantly in the survey $37.1 \%$ (10). The study object for the educational processes has diversified to the technologies used with AVA, WebQuest, Teleconference, radio, virtual playbook, multimedia, and hypermedia, as well as individualized systems to meet the need for improvement in the teaching-learning process. Thus, the creation of systems/software was observed in 33.3\% (09) of the researches, characterizing the need for individualized attention of the weaknesses of teaching-learning. National surveys showed greater concentration in the central-western regions of the country and for international research, the prevalence was more present in the United States. The Table 3 describes the focus of educational technology used for health professionals (Table 3). The development and testing of the technologies were mainly used in the graduation of medical and nursing academics. The forms of technologies were diversified to synchronous and asynchronous forms, the creation of specific technological systems, the technology that was predominant for virtual education previously as AVA was cited in only 4 studies. Thus, simulations, 3D scenarios, audios, videos, software creation, and alternative platforms were well explored for virtual education. The used resources show that the technologies are still represented for the textual form $40,7 \%$ (11), however, it observes an increasing need of the use of images as audiovisual form explored in the majority of educational processes described 59,3\% (16). In addition, it emphasizes the use of innovative technologies for professional education such as the use of radio and the application of play activities.

\section{Discussion}

The construction of a distance course in a virtual learning environment enables the expansion of possibilities for professional growth independent of the training area (health, human or exact). When analyzing the use in the health area, the possibility of converting traditional medical education is observed, through a model where students direct their learning focus from diverse educational tools, such as: video conferences, virtual forum, virtual rooms, among others. ${ }^{8,15,17}$ In view of the identified studies, it was observed that the methods that used the website in its development and carried out tests with users comparing the group with use of distance methodology with control groups obtained significant results for the group tested with the educational material developed. ${ }^{10,18,31}$ The Oliveira study did not identify a significant difference in the results between the group that used the multimedia methodology and the control group, but it was well accepted by the users. ${ }^{24}$ Some methods did not perform tests with comparative groups, but were considered favorable for learning and very well accepted in the evaluation of the users. ${ }^{8,10,26,28}$ The different methods used since interacting with distance instructor, material available for self-learning, videos, teleconferencing, among others, showing that education is not limited to expositive classes. The use of the Moodle platform also had a positive impact on students, ${ }^{10,13}$ presented better practical performance after their use ${ }^{13}$ and has been emerging as a tool in virtual learning. ${ }^{33}$ Among the teaching tools developed, the software was identified to ascertain the accuracy of diagnoses and technical skills ${ }^{16,22}$ in which, academics presented better performance after the use. ${ }^{22}$ The interaction with specialists in the area promoted a greater sense of support, ${ }^{20}$ also made it possible to exchange experiences among academics, teachers, institutions and other interest groups. ${ }^{9}$ One of the studies presented the development of a 3-D environment for anatomy learning, which can be developed by a specialist through a simplified system of immersive content creation. This system allows animations and other interactive features that enable the active demonstration of anatomical concepts. ${ }^{34}$ Methods that allow immersion to lead the student to a greater sense of realism, if used as a teaching technique, can aid in the retention of learning.

Among the methods were also identified the use of little traditional techniques such as radio soap opera. This technique was used by means of an Educational Radio, internet or download. The discipline of Scientific and Ethical Methodology was used specifically. The screenplays of the radio soap opera were based on subjects covered as abortion, death penalty, plagiarism, and ethical training. The method was well accepted by students, but technical problems were identified 
that could undermine this educational format. ${ }^{25}$ Another study used asynchronous technology of images for thyroid and parathyroid surgery filmed by a voice-activated robot arm. Subsequently, these images were reviewed by a group of surgical residents to evaluate important anatomical sites in the procedure performed. Residents also assessed the quality and clarity of the image. With this method, it is possible to reach remote places for discussion of surgical protocols, critical anatomical structures, surgical procedures, intercurrences, as well as reaching a larger number of students. Several researches have used mixed methods in the educational process of health professionals. . $^{12,16,21,28,30,32}$ The association of methods leads to different approaches or situations of the same subject, which can generate in the student a greater interest due to the dynamics. However, it should also be analyzed how different methods can be limited in the possibility of presenting the content in a complete way or to the necessary degree of professional learning. New educational technologies from information technology will enhance and strengthen learning capacity. For such, the students' attitude towards the new paradigm must also be changed. It will be up to the student himself to know how to search and select the new information, separating the useful ones from the useless ones. ${ }^{12,13,24}$ In order to build a successful virtual educational proposal, it is necessary to consider the quality of the didactic material, the choice of the teaching support platform and the methodology adopted. In this way, it becomes possible to stimulate the search for new experiences for this modality of distance learning. ${ }^{17,35}$ The testing and validation of educational technologies strengthen distance education in order to promote the shortening of geographic distances and the construction of multicentre relationships. The use of the Internet allows the exchange between universities and research centers of different locus of faster form, besides allowing the simulation of clinical and surgical cases, as well as the real-time transmission of the texts, animations, audio, and video. ${ }^{12,13,24}$

Table 2 Characterization of scientific production on educational processes for health professionals - Manaus AM, Brazil, 2018

\begin{tabular}{|c|c|c|c|}
\hline Author & Location & Method & Type of process \\
\hline Ângelo MF \& Schiabel $\mathrm{H},{ }^{8}$ & São Paulo University, Brazil & $\begin{array}{l}\text { Creation of a computational scheme } \\
\text { installed in a "site" associated to the } \\
\text { "homepage" }\end{array}$ & Technology developed \\
\hline Arantes ACC et al., $2013^{9}$ & $\begin{array}{l}\text { Federal University of the State of Rio de Janeiro, } \\
\text { Brazil }\end{array}$ & Use of teaching tools in Telemedicine & $\begin{array}{l}\text { Technology developed } \\
\text { and tested }\end{array}$ \\
\hline Autry AM et al., $2003^{10}$ & University of California, San Francisco, USA & $\begin{array}{l}\text { Use of video communication for } \\
\text { learning }\end{array}$ & Tested technology \\
\hline Braga CSR et al., 2016 ${ }^{11}$ & $\begin{array}{l}\text { GEPEETEC - Study Group on Research and } \\
\text { Extension in Stomatology and Technology and } \\
\text { NEAD - Center for Distance Education in Piauí, } \\
\text { Brazil }\end{array}$ & Using the Moodle system for learning & Tested technology \\
\hline Clauson $\mathrm{KA}^{12}$ & $\begin{array}{l}\text { Nova Southeastern University College of } \\
\text { Pharmacy, Florida, USA }\end{array}$ & Testing a University Response System & Tested technology \\
\hline Domenico EBL \& Cohrs CR ${ }^{13}$ & $\begin{array}{l}\text { Paulista Nursing School and Federal University } \\
\text { of São Paulo, Brazil }\end{array}$ & Using the Moodle Platform & Tested technology \\
\hline Freitas LV et al., ${ }^{14}$ & Federal University of Ceará, Brazil & $\begin{array}{l}\text { Development and validation of an } \\
\text { educational hypermedia }\end{array}$ & $\begin{array}{l}\text { Technology developed } \\
\text { and tested }\end{array}$ \\
\hline Gonçalves GR et al., ${ }^{15}$ & São Paulo University, Brazil & $\begin{array}{l}\text { Educational proposal with multimedia } \\
\text { resources }\end{array}$ & Technology developed \\
\hline Jensen $\mathrm{R}$ et al., ${ }^{16}$ & $\begin{array}{l}\text { Public University of the State of São Paulo, } \\
\text { Brazil }\end{array}$ & $\begin{array}{l}\text { Development and evaluation of } \\
\text { software that verifies the diagnostic } \\
\text { accuracy }\end{array}$ & $\begin{array}{l}\text { Technology developed } \\
\text { and tested }\end{array}$ \\
\hline John $\mathrm{BA}^{17}$ & $\begin{array}{l}\text { University of Brighton, Brighton, United } \\
\text { Kingdom }\end{array}$ & Online System Creation & Technology developed \\
\hline Liaw SY et al., ${ }^{18}$ & Singapore Hospital, Singapore & Creation of a simulation system & $\begin{array}{l}\text { Technology developed } \\
\text { and tested }\end{array}$ \\
\hline Lima MA et al., ${ }^{19}$ & Federal University of Ceará, Brazil & $\begin{array}{l}\text { Development of the virtual booklet on } \\
\text { eye self-examination for people with } \\
\text { HIV / AIDS. }\end{array}$ & $\begin{array}{l}\text { Technology developed } \\
\text { and tested }\end{array}$ \\
\hline Locatis $\mathrm{C}$ et al., ${ }^{20}$ & $\begin{array}{l}\text { University of Puerto Rico Medical Campus, San } \\
\text { Juan, Puerto Rico, USA and National Center for } \\
\text { Biotechnology Information, National Library of } \\
\text { Medicine, Bethesda, Maryland, USA }\end{array}$ & Distance Learning using 3D & Technology tested \\
\hline Locatis $\mathrm{C}$ et al., ${ }^{21}$ & University of Alabama at Birmingham, USA & $\begin{array}{l}\text { Performance testing and instruction and } \\
\text { technology classifications }\end{array}$ & Tested technology \\
\hline Lopes ACC. ${ }^{22}$ & Integrated Colleges Teresa D'Ávila, Brazil & $\begin{array}{l}\text { Construction of educational software } \\
\text { for teaching and learning }\end{array}$ & $\begin{array}{l}\text { Technology developed } \\
\text { and tested }\end{array}$ \\
\hline
\end{tabular}


Table Continued..

\begin{tabular}{|c|c|c|c|}
\hline Author & Location & Method & Type of process \\
\hline Moterle RR et al., ${ }^{23}$ & University of Western Santa Catarina, Brazil & $\begin{array}{l}\text { Educational Radio in the teaching- } \\
\text { learning process }\end{array}$ & $\begin{array}{l}\text { Technology developed } \\
\text { and tested }\end{array}$ \\
\hline Oliveira EFB et al., ${ }^{24}$ & Federal University of São Paulo, Brazil & $\begin{array}{l}\text { Multimedia computerized educational } \\
\text { program }\end{array}$ & Tested technology \\
\hline Olmsted JL., ${ }^{25}$ & $\begin{array}{l}\text { University of Minnesota Institutional, } \\
\text { Minnesota, USA }\end{array}$ & $\begin{array}{l}\text { Testing learning forms (synchronous } \\
\text { and asynchronous) }\end{array}$ & Tested technology \\
\hline Pereira MCA et al., ${ }^{26}$ & São Paulo University, Brazil & Creating and Evaluating a WebQuest & $\begin{array}{l}\text { Technology developed } \\
\text { and tested }\end{array}$ \\
\hline Rafiq A et al., ${ }^{27}$ & $\begin{array}{l}\text { Virginia Commonwealth University, Virginia, } \\
\text { USA }\end{array}$ & $\begin{array}{l}\text { High resolution image validation for } \\
\text { asynchronous education }\end{array}$ & Tested technology \\
\hline Reynolds PA et al., ${ }^{28}$ & $\begin{array}{l}\text { King's College London Dental Institute, } \\
\text { London, England }\end{array}$ & $\begin{array}{l}\text { Use of PADS Portable Digital } \\
\text { Assistants }\end{array}$ & Tested technology \\
\hline $\begin{array}{l}\text { Robertson JL \& Shrewsbury } \\
\text { RP }^{29}\end{array}$ & University of North Carolina, USA & $\begin{array}{l}\text { Creation and testing of a new form of } \\
\text { Teleconference }\end{array}$ & $\begin{array}{l}\text { Technology developed } \\
\text { and tested }\end{array}$ \\
\hline Shyu FM ${ }^{30}$ & University of Taiwan, Taiwan & Online System Creation & Technology developed \\
\hline Smith PJW et al., & $\begin{array}{l}\text { University of Edinburgh, Scotland, United } \\
\text { Kingdom }\end{array}$ & $\begin{array}{l}\text { innovative platform with virtual case } \\
\text { scenarios }\end{array}$ & Tested technology \\
\hline Szymas $\mathrm{J}^{32}$ & University Medical School, Poland & $\begin{array}{l}\text { Creation and use of telepathology } \\
\text { system }\end{array}$ & $\begin{array}{l}\text { Technology developed } \\
\text { and tested }\end{array}$ \\
\hline $\begin{array}{l}\text { Valenzuela-Zambrano B \& } \\
\text { Pérez-Villalobos } \mathrm{MV}^{33}\end{array}$ & Universidad de Concepción, Chile & $\begin{array}{l}\text { Moodle software and its relation } \\
\text { with the promotion of self-regulated } \\
\text { learning. }\end{array}$ & Tested technology \\
\hline Warren W \& Brinkley JF ${ }^{34}$ & University of Washington, Seattle, WA & Creation of a system & Technology developed \\
\hline
\end{tabular}

Source: authors, 2018

Table 3 Educational processes and their applications - Manaus, AM, Brazil, 2018.

\begin{tabular}{|c|c|}
\hline Author & Description of the Educational Process \\
\hline Ângelo MF \& Schiabel $\mathrm{H}^{8}$ & $\begin{array}{l}\text { Implementation of a computational scheme installed in a "site" associated to the "homepage" of the Laboratory of Analysis } \\
\text { and Image Scanning to provide a procedure of interactivity with the remote user in the elaboration of the report from the } \\
\text { analysis of mammographic images through the network, with automatic evaluation of the opinion issued. }\end{array}$ \\
\hline Arantes ACC et al., ${ }^{9}$ & $\begin{array}{l}\text { Development of two teaching-learning tools entitled "Youknow" and "SANA" and describes the experience of teachers } \\
\text { and medical students with these new teaching methodologies }\end{array}$ \\
\hline Autry AM et al., ${ }^{10}$ & $\begin{array}{l}\text { It was studied the feasibility and acceptability of using Internet video communication to teach and evaluate surgical skills } \\
\text { in a low resource environment. }\end{array}$ \\
\hline Braga CSR et al., ${ }^{11}$ & Constructed and validated a virtual learning object (VLO) on intestinal elimination stomas using the Moodle platform \\
\hline Clauson $\mathrm{KA}^{12}$ & $\begin{array}{l}\text { Evaluated the impact of an Audience Response System (ARS) on the involvement of students in a multi-campus pharmacy } \\
\text { faculty with an online questionnaire was designed and administered to measure the impact of an ARS on student } \\
\text { involvement, distance education, projected use and satisfaction among pharmacy students for a course between } 3 \text { sites via } \\
\text { transmission of synchronous video. }\end{array}$ \\
\hline Domenico EBL \& Cohrs CR ${ }^{13}$ & $\begin{array}{l}\text { Compared the improvement of knowledge and skills of undergraduates who participated in the activities proposed in the } \\
\text { Virtual Learning Environment, Moodle, during the period of hospital practice in an intensive care unit. }\end{array}$ \\
\hline Freitas LV et al., ${ }^{14}$ & $\begin{array}{l}\text { Described the process of development and validation of an educational hypermedia for undergraduates and nursing } \\
\text { professionals regarding the technique of performing the prenatal physical examination. Hypertexts, hyperlinks, audiovisual } \\
\text { resources, communication spaces, evaluations and support material were developed. }\end{array}$ \\
\hline Gonçalves GR et al., ${ }^{15}$ & $\begin{array}{l}\text { Developed a virtual educational proposal, using multimedia resources, aiming to innovate, dynamize and diversify spaces } \\
\text { of communication and interaction, favoring the process of teaching autonomous and reflective learning of nurses. }\end{array}$ \\
\hline Jensen R et al., ${ }^{16}$ & $\begin{array}{l}\text { Development and evaluation of software that verifies the diagnostic accuracy of nursing students. The software was based } \\
\text { on a model that uses fuzzy logic concepts in PERL, MySQL database for Internet access and the 2007-2008 NANDA-I } \\
\text { classification. The technical quality and usability of the software were evaluated using specific instruments. }\end{array}$ \\
\hline
\end{tabular}


Table Continued..

\begin{tabular}{|c|c|}
\hline Author & Description of the Educational Process \\
\hline John BA., ${ }^{17}$ & $\begin{array}{l}\text { Use of a social networking platform to establish an informal code of conduct, modeling and moderating appropriate online } \\
\text { professionals behavior. }\end{array}$ \\
\hline Liaw SY et al., ${ }^{18}$ & $\begin{array}{l}\text { The design, development and evaluation of an interactive multimedia web simulation for the development of competencies } \\
\text { of nurses in acute nursing care. }\end{array}$ \\
\hline Lima MA et al., ${ }^{19}$ & $\begin{array}{l}\text { Described the process of developing the virtual primer on ocular self-examination for people with HIV / AIDS. The } \\
\text { methodological proposal followed the five steps recommended by Falkembach: analysis and planning, modeling, } \\
\text { implementation, evaluation and distribution. }\end{array}$ \\
\hline Locatis $\mathrm{C}$ et al., ${ }^{20}$ & $\begin{array}{l}\text { It offered mini-courses that imply the application of concepts in biochemistry and genetics to research genomic databases } \\
\text { and other sources of information. These courses are highly interactive and involve the use of 3D molecular visualization } \\
\text { software that can be definitely computationally. }\end{array}$ \\
\hline Locatis $\mathrm{C}$ et al., ${ }^{21}$ & $\begin{array}{l}\text { Performance testing and instruction and technology classifications, factors influenced by the sense of presence, are } \\
\text { compared in four conditions involving different environments and degrees of physical presence of the student: 1) co- } \\
\text { located videoconferencing, 2) co-located webcast, 3) dispersed videoconferencing, and 4) dispersed webcast. }\end{array}$ \\
\hline Lopes $\mathrm{ACC}^{22}$ & $\begin{array}{l}\text { Constructed an educational software for the teaching-learning technique of delayed urinary catheterization and to compare } \\
\text { the knowledge apprehension about the urinary catheterization technique of delay before and after the application of an } \\
\text { educational software. }\end{array}$ \\
\hline Moterle RR et al., ${ }^{23}$ & $\begin{array}{l}\text { Contributions of Radio Educativa in the teaching-learning process of the disciplines of Scientific Methodology and Ethics } \\
\text { and Society, offered by the University of the West of Santa Catarina (Unoesc), in the distance modality, through a radio } \\
\text { soap opera, highlighting ethical conflicts in debate in society: abortion, death penalty, plagiarism and ethical training. }\end{array}$ \\
\hline Oliveira EFB et al., ${ }^{24}$ & $\begin{array}{l}\text { Evaluated the effectiveness of a computerized educational program with multimedia resources as a teaching tool for } \\
\text { students of the second year of the undergraduate course in Medicine. }\end{array}$ \\
\hline
\end{tabular}

Olmsted $\mathrm{JL}^{25}$

Determines whether students face to face in a classroom with an instructor execute differently than their counterparts in a Distance Learning program

Creation and evaluation of a WebQuest, in the theme "material resource management in nursing". It was developed in three stages: Step 1 consisted of the pedagogical aspect of elaboration and definition of the content, Step 2 involved organization of the content, inclusion of images and completion of the finishing and Step 3 corresponded to the availability to the students.

Rafiq A et al., ${ }^{27}$

The study validated the use of asynchronous education with high quality optical capture for distance education and collaboration and open surgeries.

Described a simple technical assessment of access, security issues, and use of wireless networked Portable Digital

Reynolds PA et al., ${ }^{28}$

Robertson JL \& Shrewsbury $\mathrm{RP}^{29}$

Shyu FM $\mathrm{FM}^{30}$

Smith PJW et al., ${ }^{31}$

Szymas $\mathbf{J}^{32}$

Valenzuela-Zambrano B \& Pérez-Villalobos $\mathrm{MV}^{33}$

Warren W \& Brinkley JF ${ }^{34}$
Assistants (PDAs) in a dental clinic and reports a pilot study investigating the educational use of student PDAs to access a virtual learning environment (VLE) in a dental clinic.

Designed, implemented and evaluated the effectiveness of using a live video teleconferencing system to connect the main campus and a satellite campus during the laboratory composition exercises in a pharmacist program.

Creation of a system to establish a virtual medicine school as the platform of the e-learning center, which integrates collaboration and self-directed learning environment through group, classroom and library.

Evaluated the impact of an e-learning program in surgical sciences to support the academic development of surgical trainees during their preparation for professional examination with an innovative platform with virtual case scenarios based on common surgical conditions addressed by the curriculum relating to surgery training.

Creation and use of telepathology system and multimedia database for education. It is used for self-education, testing, services and for pathology exams, i.e. for dentistry students and medical students in terms of self-education and individual examination services.

Description of the main incentive activities of self-regulated learning, virtual teaching platforms and review of research using Moodle.

Using a Biolucida system allows an author to create a 3D Scene based on virtual reality complete with animation, object behaviors and audio narration.

\section{Conclusion}

The research verified the use of a technological variety for the educational process with emphasis on health professionals. Faced to the studies, it was observed that the test of existing technologies were the most reported, followed by considerable publications with concomitant use of development and tests of learning technologies. The diversity of technologies for which they characterized innovations were represented by the AVA, WebQuest, Teleconference, radio, virtual playbook, multimedia, and hypermedia, being the graduation of health professionals, such as medicine and nursing, the most contemplated areas. The resources used show that technologies with audiovisual format were widely explored in the educational processes, with an innovative highlight for the use of radio and the application of play activities. The limitations of the present study are directed to the difficulty of online access in the whole of some studies selected for reading, fact that made it impossible to comprehend detailed and in depth the context of the technology developed and tested only with the summary of the intended article. The search for technological innovations for the educational process is a national and international theme since the studies were homogeneously distributed for this aspect. Thus, it highlights the growth of tools that facilitate and encourage this 
process to attend the learning needs of health professionals and thus contemplate those of difficulty of access to large centers, face-to-face courses and complements in the understanding of deficit issues. These findings reflect the technological evolution in the digital era and are constantly seeking innovative strategies to meet the demands of the job market, especially in universities. Faced with this, the incessant search for adaptations of existing technologies and new discoveries of educational processes will benefit learning and reduce knowledge gaps with these digital facilitators.

\section{Funding details}

Samsung Electronics of the Amazon LTDA by means of the Amazon Informatic Law, it foments research and technological development of the region in partnership with the University of the State of Amazonas.

\section{Acknowledgments}

We thank Samsung Electronics of the Amazon LTDA by means of the Amazon Informatic Law, it foments research and technological development of the region in partnership with the University of the State of Amazonas, and the Research and Development Center UNASUS Amazonia of the said university.

\section{Conflict of interest}

Authors declare that there is no conflicts of interest.

\section{References}

1. Decree n. 2,494, dated February 10, 1998. Brasília; 1998.

2. Ferreira RGS, Nascimento JL, Paim LAB, et al. Technologies in EAD and its use in the context of Nursing teaching. Revista Saúde e Desenvolvimento. 2017;11(9):340-354.

3. Brazilian Association of Distance Education. Census EAD.BR Analytical Report on Distance Learning in Brazil 2016. Curitiba; 2017.

4. Costa SS, Cazella S, Rigo SJ. Mining data on the performance of students of continuing education courses in the EAD modality: A case study on school evasion in UNA-SUS. Rev Novas Tecnol na Educ. 2014;1(2):1-10.

5. Costa MA, Santos NB, Rodriguez JAF, et al. EAD and Health Approach between the areas from the experience of a course at the Oswaldo Cruz Foundation. Ead em foco. 2012;2:47-57.

6. Bissolotti K, Pereira ATC. Gamma Scenario Proposal for the Virtua Learning Environment Tear_AD. Ergodesign e HCI. 2016;2(4):64-71.

7. Whittemore $\mathrm{R}, \mathrm{Knafl} \mathrm{K}$. The integrative review: Updated methodology. J Adv Nurs. 2005;52(5):546-553.

8. Ângelo MF, Schiabel H. A tool for training in the evaluation of mammographic images via the Internet. Radiol Bras. 2002;35(5):259-265.

9. Arantes ACC, Cardozo ATS, Frajhof L, et al. Usability of telemedicine as a collaborative teaching platform for medical students. J Bras Telessaúde. 2013;2(4):131-137.

10. Autry AM, Knight S, Lester F, et al. Teaching surgical skills using video internet communication in a resource-limited setting. Obstet Gynecol. 2013;122(1):127-131.

11. Braga CSR, Andrade EMLR, Luz MHBA, et al. Construction and validation of a virtual learning object on intestinal elimination stoma. Invest educ enferm. 2016;34(1):120-127.
12. Clauson KA, Alkhateeb FM, Singh-Franco D. Concurrent use of an audience response system at a multi-campus college of pharmacy. Am J Pharm Educ. 2012;76(1).

13. Domenico EBL, Cohrs CR. Moodle platform in the construction of knowledge in Intensive Therapy: experimental study. Acta Paul Enferm. 2016;29(4):381-389.

14. Vieira LF, Teles LMR, Lima TM, et al. Prenatal physical examination: construction and validation of educational hypermedia for Nursing. Acta Paul Enferm. 2012;25(4):58.

15. Goncalves TD, Crenitte PAP. Development of a CD-ROM on written language for the continuing education of elementary school teachers. $J$ Appl Oral Sci. 2011;19(6):560-566.

16. Jensen R, Lopes MHBM, Silveira PSP, et al. Development and evaluation of software that verifies the diagnostic accuracy. Rev da Esc Enferm da USP. 2012;46(1):184-191.

17. John BA. Kinship - King 'S Social Harmonisation Project . Pilot Pha Se of a Social Network for Use in Higher Education ( $\mathrm{He}$ ). Bull Gr Int Rech Sci Stomatol Odontol. 2012;51(3):19-22.

18. Liaw SY, Wong LF, Chan SWC, et al. Designing and evaluating an interactive multimedia web-based simulation for developing nurses' competencies in acute nursing care: Randomized controlled trial. $J$ Med Internet Res. 2015;17(1):e5.

19. Lima MA, Pagliuca LMF, Nascimento JC, et al. Virtual guide on ocular self-examination to support the self-care practice for people with HIV/ aids. Rev esc. enferm. USP. 2014;48(2):285-291.

20. Locatis $\mathrm{C}$, Vega A, Bhagwat $\mathrm{M}$, et al. A virtual computer lab for distance biomedical technology education. BMC Med Educ. 2008;8:1-8.

21. Locatis C, Berner ES, Hammack G, et al. Communication and proximity effects on outcomes attributable to sense of presence in distance bioinformatics education. BMC Med Educ. 2011;11(1):1-7.

22. Lopes AC, Ferreira AA, Fernandes JA, et al. Construction and evaluation of educational software on urinary indwelling catheters. Rev esc enferm. USP. 2011;45(1):210-217.

23. Moterle RR, Rover A, Collusso LC, et al. Rádio Educativa Unoesc FM as didactic resource in Distance Education. Roteiro. 2007;32(1):37-60.

24. Oliveira EFB. Efficacy of a multimedia simulator in the teaching of basic techniques of video-surgery in the undergraduate medical course. Rev Bras Educ Med. 2007;31(3):312-312.

25. Olmsted JL. Direct assessment as a measure of institutional effectiveness in a dental hygiene distance education program. J Dent Educ. 2014;78(10):1460-1467.

26. Pereira MCA, Melo MRAC, Silva ASB, et al. Evaluation of a Webquest on the Theme "Management of Material Resources in Nursing" by Undergraduate Students. Rev Lat Am Enfermagem. 2010;18(6):1107-1114

27. Rafiq A, Moore JA, Doarn CR, et al. Asynchronous confirmation of anatomical landmarks by optical capture in open surgery. Arch Surg. 2003;138(7):792-795.

28. Reynolds PA, Harper J, Dunne S, et al. Portable Digital Assistants (PDAs) in dentistry: Part II - Pilot study of PDA use in the dental clinic. Br Dent J. 2007;202(8):477-483.

29. Robertson JL, Shrewsbury RP. Video teleconferencing in the compounding laboratory component of a dual-campus doctor of pharmacy program. Am J Pharm Educ. 2011;75(9):181.

30. Shyu FM, Liang YF, Agnes Hsu WT, et al. A problem-based e-learning prototype system for clinical medical education. Stud Health Technol Inform. 2004;107:983-987. 
31. Smith PJW, Wigmore SJ, Paisley A, et al. Distance learning improves attainment of professional milestones in the early years of surgical training. Ann Surg. 2013;258(5):838-843.

32. Szymas J. Teleeducation and telepathology for open and distance education. Anal Cell Pathol. 2000;21(3-4):183-191.

33. Valenzuela-Zambrano B, Pérez Villalobos MV. Self-regulated learning through the Moodle virtual platform. Educ Educ. 2013;16(1):66-79.
34. Warren W, Brinkley JF. Knowledge-based, interactive, custom anatomical scene creation for medical education: the Biolucida system. AMIA Annu Symp Proc. 2005:789-793.

35. Gonçalves GR, Peres HHC, Rodrigues RDC, et al. Virtual educational proposal in cardiopulmonary resuscitation for the neonate care. Rev esc enferm USP. 2010;44(2):413-420. 